\title{
TEACHING SCIENCE FOR UNDERSTANDING: THE PROJECT-BASED APPROACH
}

\section{SAID SUWAIBA AHMAD}

\section{Abstract}

The paper focuses on project - based approach generally which is an approach that relies on the notion that leamers learn better and more meaningful if given opportunity to participate in a project and from their experiences. Projects based instruction was discussed. Project based learning was also examined. The paper concluded by identifying conditions that can affect effective utilization or hinder the project based approach.

\section{INTRODUCTION}

In the past two decades, several initiatives have been taken to reform the teaching and learning of science. Some of these reforms include the implementation of inquiry - based science curricular in the US (Cohen, 1997). Despite all these reforms, the teaching and learning of science in most classrooms is characterized by the chalk - talk laboratory method. Research in Nigeria have also identified that teaching method employed by most teachers is Teacher centered (Ahmed 2009).

Students are learning science without actually understanding it which means that science teachers are relying on teaching methods or strategies that are ineffective for promoting understanding of science. Lack of understanding science is not only a problem for students, but also a problem for the nation. As science has been identified as one of the key agent of development, Nigeria been a developing country must ensure understanding and application of science. Among the best approaches to ensuring effective learning and understanding of science is project based approach. This paper focuses on project based approach. its instruction and project based learning.

\section{PROJECT BASED APPROACH (PBA)}

The project - based approach (PBA) is born out of the broader Epistemological framework of constructivism (Piaget, 1985), which has a long standing history in education. As early as 1900s, John Dewey, the father of progressive education support "learning by doing"; he promotes teaching strategies that help students actively engaged in learning about topics relevant to their lives. PBA relies on the notion that if learners are given opportunities to construct their own meaning based out of their experiences of participating in a project with their peers, then multiple opportunities of meaningful learning occur (Bhattacharya and Bhattacharya, 2009).

By directly engaging the learner with the science (or content-related) problem, a PBA can create authentic learning experience through which learners discover facts, concepts, or principles on their own. A systematic inquiry into the role of PBA in science instruction has revealed its value in developing scientific investigative skills among 
students (Krajcik, Blumenfield, Marx and Soloway, 2001). There is also evidence that PBA, when integrated with technology, can enhance students' performance by helping them internalize various concepts and their application in science (Ryser. Beeker and Mckenzie. 1995).

Bransford and Stain (1993) reported that PBA yields a production or performance that demonstrates learner's ability to apply new concept in complex, and meaningful ways. PBA offers learners an experimental, interactive, investigative and croperative form of iearning (Wills and Mehlinger, 1996). By incorporating personal experience and social interaction with peers in the learning process, PBA allows learners to connect, reflect on, and integrate new information into their preexisting knowledge. The instructor's (Teacher) role is mainly that of a facilitator who fosters a learnercentered environment to create autonomous learners (Marx, Blumenfield, Krajcik, \& Soloway 1997). Thus learners became skilled at developing evidence - based arguments by discovering facts, concept \& principles in their informal interaction with each other, such that learners can act as mentors to one another (Bhattacharyya and Bhattacharyya 2009).

An integral part of PBA involves collaborative learning. in which peers work together and serve as mentors for one another through formal and informal conversation. Informal conversation leading to the internalization of concept in PBA reveals the importance of providing a non-threatening learning environment in which peers provide models of training for each other. Several studies support the value of such training in enhancing teaching and learning (Glazer, 2004).

Katz and Chard (2000), divided PBA into three phases, planning, creating and processing. Each phase requires collaborative learning and cognitive apprenticeship. However, although the three phases may be described separately, it is important to understand that the experiences of project - based learning is an interactive one. Learners do not move in an unidirectional or linear progression from the planning, creating to processing phase. Instead, they move back and forth from one phase to another based on the ways they construct knowledge.

In planning phase, learners collaboratively choose a project, set goals and identify necessary resources. The second phase, creating, involves collecting data and other relevant information for the project. During this phase learners might choose to revise their topic based on feasibility or access to resources, etc. In processing, the third phase of project - based learning, the learners reflect on their own projects, assess how well they have accomplished the goals set during the planning phase and revise any goals if they need to.

Additionally, during the final phase, learners share product and/or performance. with other members of the class and reflect on the learning process and the product through dialogue and feedback.

\section{PROJECT BASED INSTRUCTION}

Colley (2005) argued that the most appropriate instructional approach that secondary school science teachers can use to teach science for understanding is project - based science instruction. 
Project - based sciense instruction is the only instructional mithod that makes science classroom function like mini experimental stations, research laboratories and science agencies. It is instructional approach that is driven by well - defined student research question. facilitated by caring and competent teacher. In project - based science classroom, students, pose research questions and conduct extended studies to find answer to their questions within the context of a unit, curriculum or program of study. Teachers in a project based science classroom, perform more than the role of "lesson planners", "knowledge providers" and "classroom managers". Instead they act as facilitators, mentors, resource persons, advisors, scientists, listeners, learners and leaders in science classroom. They work with students to identify projects that they are interested in and create learning environments that allow them to gather resources, plant, implement, evaluate and report on their projects.

\section{PROJECT - BASED LEARNING (PBL)}

Project - based learning is a student centered instructional approach used to promote active and deep learning by involving students in investigating real world issues in collaborative environment.

PBL is a comprehensive, deep learning approach to classroom teaching and learning that engages, students in the investigation of authentic problems (Blumenfield et al. 1991). Adderley et al. (1997) put forward an important definition of PBL.

- It involves the solution of a problem, though not necessary set by the student himself/herself.

- It involves initiative by the student or group of student, and necessitates a variety of educational activities.

- It usually results in an end product (e.g. report, computer programme. a model).

- It is often goes on for a considerable period of time.

- $\quad$ Tear hing staffs assumes advisory roles instead of authoritarian.

Problem - solving is essential to the development of expertise; thus, student should be exposed to real - work problems from the outset of education (Helle, Tynjala and Olkenoura, 2006). The driving question or problem is essential in PBL as it helps to drive activities in creating the final product that address the questions (Blumenfield, et al., 1991).

Krajcik, Czerniak and Berger (1991), define PBL as an approach that engage students in exploring important and meaningful questions through a series of investigations and collaborative activities. These students ask questions, collaborative with each other in designing their investigation activities, collect and analyze data, share ideas, draw conclusions and create final products (Blumenfield, et al., 2001).

PBL is an instructional approach centered on learners learning activities where the learners are more autonomous as they construct meaningful artifacts through their learning process. 
Colley (2000) outline strategies for implementing project based approach to include:

- Administer pre - assessment to determine students' knowledge. process skills and dispositions in the specific subject. theme or topic. introduce the students to PBA. Explain the expectations of project based instruction.

- Emphasize that collaboration is a must. This is because most scientific investigation requires collaboration in task such as fieldwork. instrument development, testing and collection of data.

- $\quad$ Discuss the advantages as well as disadvantages of working in groups outweigh its disadvantages.

- Note that as they work in groups, they will have to complement each other's weakness with each other's strengths. make constructive criticism as opposed to destructive criticism. and take collective responsibility.

- Divide the class into small manageable groups of three or four tend to work better than larger groups. Where possible, make sure that each group is balanced in terms of gender, ethnicity, race, academic ability and socio - economic background. Tell students that they will be working in their groups throughout and as young scientist they will be required to work collaboratively and to divide the responsibility among themselves. Tell them that you will hold each accountable for its own learning.

- Explain that each group is required to identify a question that they will investigate within a specific time frame, resources and context.

- Ask each group to present their research during the presentation. encourage the groups to evaluate each other's research question.

- Ask each group to transform and come up with a research plan. Research plans should include research procedure, tools and materials required, time to complete project, roles and responsibilities.

- Discuss with the students a collective timetable in which to begin and complete their projects.

- Ask each group to implement its research plan. This will include identifying and selecting instrument and tools or collecting and recording data.

- Discuss the basic methods of analyzing quantitative and qualitative data.

- Discuss the protocol of presentation and criteria that will be uses for evaluating project reports.

- Administer post assessment.

Likely challenges that teachers may encounter in implementing Project based approach: 
- Inability of teachers to provide learning environment that are full of challenging problems for students to solve.

- The approach could be time consuming if not properly planned.It requires time in terms of instructional planning, scheduling activities. developing collaborative relationships, implementing activities. supervising students team work. assessing student's projects and learning to use technology appropriately.

- $\quad$ Project based approach demands that resources be made available for students to carry out the projects of their choice. This means that tools, materials, equipment's, hardware and software must be available to all students.

- Project based approach require students to conduct extended projects. which means sometimes doing work outside of school. Students may need parental or guardian support to pursue project to the end.

- The methods may not be appropriate in cases where learner lack the requisite intellectual ability, social skills or attributes to participate effectively in such projects.

- The method may be less effective if introduced at the beginning of a term, when learners are less likely to know one another and the teacher may not have sufficient knowledge of each student's predispositions, strengths and weakness.

Recommendation on possible solution to identified challenges

- Teachers should create an enabling and challenging environment that would foster effective learning.

- Teachers should plan adequately for the approach. Teachers most schedule and manage time.

- Resources required for this approach must be made available for the teachers and students.

- The school should encourage and involve parents in student's activities. In a school where there is an active parental involvement program, Project based approach will thrive because students are more likely to get the outside support they need to work on and complete their projects.

- $\quad$ Students should be encouraged to develop the required attributes for effective utilization of the approach.

- The approach should be introduced after the teacher is able to assess the student and there is an established relationship amongst the students.

\section{CONCLUSION}

Science and technology are key ingredients for development, therefore Nigeria must identify all avenues that could ensure effective development of Science and Technology. How students learn Science affects their scientific 
development, hence methods of teaching that encourage learning and application of Science must be encouraged. Projectbased approach is effective in ensuring learning and understanding of Science and therefore teachers should be encouraged to adopt the method in teaching.

\section{References}

Adderly, K.; Ashwin, C.; Bradbury, P.; Goodland, S.; Greene, J.; Jenkins, D.; Rae, Wren, O. (1997). Project methods in higher education. society for Research in higher education, working party in teaching methods: Techniques group.

Ahmad S. S. (2008). Gender Differences in Attitude towards teaching and Learning Science among Senior Secondary School Students in Kano \& Jigawa State: $A n$ unpublished $M$ Ed thesis submitted to the department of Education Bayero University Kano.

Bhattacharya, S. \& Bhattacharya, K. (2009). Technology integrated Project-Based Approach in Science Education: A Qualitative study of in-service Teachers' learning experiences. Electronic journal of Science, 13 (3): 334-354.

Blumenfield, P.; Fishman, B.; Krajcik, J.; Marx, R.; \& Soloway E. (2000). Creating Usable innovations in systemic reform: Scaling up technology-Embedded Project based science in urban schools. Educational Psychologist, 35 (3): 149-164.
Bransford, J. D. \& Stein, B. S. (1993). The ideal problem solver (2nd Ed.). New York: Freeman.

Cohen, K. C. (1997). Internet Links for Science Education: StudentsScientist Partnerships: New York. NY: Plenium Press.

Colley, K. E. (2000). Project-Based Science Instruction: Radical Pedagogy, 3 (2).

Glazer, E. (2004). From a Caterpillar to a butterfly: The growth of a Teacher in Developing Technology-enhanced Mathematical investigations. Journal of Technology and Teacher Education, 12 (1).

Helle, L.; Tynjala, P. \& Olkinouro, E. (2006). Project-based learning in post-Secondary education. Theory practice and rubber sling shots; Higher Education, 51 (1): 287-314.

Katz, L. G. and Chard, S. C. (2000).Engaging Children's Minds: The Project Approach (2 $2^{\text {nd }}$ Ed.). Stanford, CT: Ablex Publishing.

Krajcik, J.; Blumenfield, P.; Marx, R., \& Soloway, E. (2001). A collaborative model for helping science teachers learn projectbased instruction. Elementary School Journal, 94 (5): 483-497.

Krajik, J. Cerniak, C. M. \& Berger C. F. (1999). Teaching Science: a project based Approach, MC Graw-Hill College. New York. 
Marx, R.; Blumenfield, P.; Krajcik, J. \& Soloway, E. (1997). Enacting project-Based Science. The Elementary School Journal. 97 (4): 431-458.

Piaget. J. (1985). The equilibrium of cognitive structures: The central problem of intellectual development. Chicago: University of Chicago Press.

Ryser, G., Beeler, J.. \& McKenzie. C. (1995). Effects of a ComputerSupported Intentional Learning Environment (CSILE) on students' self-concept, Self-regulatory behavior. and critical thinking ability. Journal of Educational Computing Research, 13 (4): 375385.

Willis, J., \& Mehlinger, H. (1996). Information technology and teacher education. In T. Buttery, E. Guyton \& J. Sikula (Eds.), Handbook of. 